\title{
ISAIAH IN 1 PETER 3:13-17 \\ Applying intertextuality to the study of the Old Testament in the New
}

\author{
Fika J van Rensburg \\ Potchefstroom University for CHE
}

Steve Moyise

University College, Chichester, UK

\begin{abstract}
Intertextuality is a postmodern literary concept that has become something of a buzz word in recent biblical studies. However, it can be fruitfully combined with more traditional approaches to illuminate the use of the Old Testament in the New. In this study of the Isaiah material quoted in 1 Peter 3:13-17, we combine historical, grammatical and structural modes of interpretation, with certain aspects of intertextuality, in order to explore the textual dynamics of this intriguing text.
\end{abstract}

\section{Introduction ${ }^{1}$}

Julia Kristeva is generally credited as the first to introduce the term intertextualite into literary discussion in 1969. Drawing on the work of Bakhtin, Kristeva suggests a dialogical relationship between "texts", broadly understood as a system of codes or signs. Moving away from traditional notions of agency and influence, she suggests that such relationships are more like an "intersection of textual surfaces rather than a point (a fixed meaning)". The notion was introduced to biblical scholars by two books in 1989. The first was a collection of essays entitled Intertextuality in Biblical Writings (Draisma 1989), containing both theoretical discussions and examples of biblical intertextuality. For Vorster (1989:21), one of the contributors to this collection of essays, intertextuality differs from Redaktionsgeschichte in three significant ways:

"First of all it is clear that the phenomenon text has been redefined. It has become a network of references to other texts (intertexts). Secondly it appears that more attention is to be given to text as a process of production and not to the sources and their influences. And thirdly it is apparent that the role of the reader is not to be neglected in this approach to the phenomenon of text."

The other book was Echoes of Scripture in the Letters of Paul, by Richard Hays. Hays does not mention Kristeva but draws on Hollander's 1981 work, The Figure of Echo: A Mode of Allusion in Milton and After. Hays is impressed by the subtlety of Hollander's analysis and asks why this has not always been the case with biblical scholars. He attempts to put this right in a number of highly regarded studies on Paul, claiming that "the most significant elements of intertextual correspondence between old context and new can be implicit rather than voiced, perceptible only within the silent space framed by the juncture of two texts" (1989:155). In short, the quoting of previous work is never simple. As Miscall (1992:44) says:

1. This introduction draws particularly on Moyise (2000:14-18). 
To recognize that a text is related to another text is both to affirm and to deny the earlier text. It is affirmed as a type of model and source, while it is denied by being made secondary to the later text, precisely by being regarded as a model and a source that has been superseded.

This study is a co-operative venture between someone who has done detailed work on the structure and meaning of 1 Peter (Van Rensburg, 1992; 1998) and someone who has worked on the concept of intertextuality (Moyise, 1995; 2000; 2002). Our aim is to demonstrate the importance of both traditional methods of interpretation and those deriving from more recent literary theory. We leave it to the reader, as all authors must, to decide whether we have been successful.

\section{Isaiah in 1 Peter}

\subsection{A preliminary survey}

The UBSGNT ${ }^{2}$ gives three sets of information that can be utilized to give a preliminary survey of the Isaiah material in 1 Peter: (1) the cross reference system at the bottom of each text page (Aland 1993:785-798); (2) the "Index of quotations" (Aland 1993:890); and the "Index of allusions and verbal parallels (Aland 1993:896-898). The following table gives a synopsis of this information:

\begin{tabular}{|l|l|l|l|}
\hline 1 Peter & $\begin{array}{l}\text { Cross references } \\
\text { Isaiah }\end{array}$ & $\begin{array}{l}\text { Index of } \\
\text { Quotations }\end{array}$ & $\begin{array}{l}\text { Index of allusions and } \\
\text { verbal parallels }\end{array}$ \\
\hline $1: 7$ & $48: 10$ & & $48: 10$ \\
\hline $1: 11$ & 53 & & 53 \\
\hline $1: 17$ & $59: 18 ; 64: 8$ & & $59: 18 ; 64: 8$ \\
\hline $1: 24-25$ & $40: 6-8$ & $40: 6-8$ & \\
\hline $2: 4$ & $28: 16$ & & $28: 16$ \\
\hline $2: 5$ & $61: 6$ & & $61: 6$ \\
\hline $2: 6$ & $28: 16$ & $28: 16$ & \\
\hline $2: 8$ & $8: 14$ & $8: 14$ & \\
\hline $2: 9$ & $9: 2 ; 43: 20-21 ; 61: 6$ & $43: 20-21$ & $9: 2 ; 42: 12 ; 61: 6$ \\
\hline $2: 12$ & $10: 3$ & & $10: 13$ \\
\hline $2: 22$ & $53: 9$ & $53: 9$ & \\
\hline $2: 23$ & $53: 7$ & & $53: 7$ \\
\hline $2: 24$ & $53: 4,12$ & & $53: 4,12$ \\
\hline $2: 25$ & $53: 6$ & & $53: 6$ \\
\hline $3: 14-15$ & $8: 12-13$ & & $8: 12-13$ \\
\hline $4: 14$ & $11: 2$ & & $11: 2$ \\
\hline
\end{tabular}

2. The UBS fourth revised edition of the Greek New Testament (UBSGNT) (cf Aland 1993:45*) acknowledges three categories of cross references:

- Quotations from biblical and non-biblical books

- Definite allusions, where it is assumed that the writer had in mind a specific passage of Scripture

- $\quad$ Literary and other parallels

The third classification is problematic in that it gives no clue as to what criteria have been used to compile it. In other words, is a literary parallel any verse which happens to contain some common words (even if they appear in a very different context) or only those verses that appear to have some connection with the text, be it structural, contextual or thematic. Moyise (2000:18-19) prefers the categories of quotation, allusion and echo. 


\subsection{The author's debt to traditional Christian exegesis}

The same index also reveals that the author of 1 Peter is greatly indebted to traditional Christian exegesis, since many of his allusions appear elsewhere in the New Testament (Aland 1993:896-898):

\begin{tabular}{|l|l|l|}
\hline Isaiah & 1 Peter & New Testament \\
\hline $8: 14$ & $2: 8$ & Luke $2: 34 ;$ Rom $9: 32$ \\
\hline $9: 2$ & $2: 9$ & Luke $1: 78-9 ; 2$ Cor $4: 6$ \\
\hline $11: 2$ & $4: 14$ & Eph $1: 17$ \\
\hline $28: 16$ & $2: 6$ & 1 Cor $3: 11 ;$ Eph $2: 20$ \\
\hline $53: 5$ & $2: 24$ & Matt $26: 27$ \\
\hline $53: 7$ & $2: 23$ & $\begin{array}{l}\text { Matt } 27: 12 ; \text { Mark } 14: 60-61 ; 15: 4-5 ; 1 \text { Cor } 5: 7 ; \\
\text { Rev } 5: 6 ; 13: 8\end{array}$ \\
\hline $53: 12$ & $2: 24$ & Matt $27 ; 38 ;$ Luke $23: 33-4 ;$ Heb $9: 28$ \\
\hline $59: 18$ & $1: 17$ & Rev $20: 12-13 ; 22: 12$ \\
\hline $61: 6$ & $2: 9$ & Rev $1: 6 ; 5: 10 ; 20: 6$ \\
\hline $64: 8$ & $1: 17$ & John $8: 41$ \\
\hline
\end{tabular}

\subsection{The author's own creative exegesis}

This leaves 6 references to Isaiah which are unique to 1 Peter $(8: 12-13 ; 10: 3 ; 42: 12 ; 48: 10$; $53: 4,6)$. The two references to Isaiah 53 are easily explained, since the author makes several allusions to the surrounding verses. He is simply expanding the tradition. Isaiah 8:12-13 could be similarly explained, since he quotes the 'stone' saying (Isa 8:14) in 1 Peter 2:8. Isaiah 42:12 is taken from the important servant song which is quoted at length in Matthew 11:5 and 12:18-21 (though not this particular verse). This leaves only Isaiah 10:3 and 48:10 that are not easily linked to traditional Christian exegesis. We may conclude then that our author was capable of original exegesis but rarely strayed from the stock passages used by Christians before him. ${ }^{3}$

\section{The context of 1 Peter 3:13-17}

\subsection{The overall structure of 1 Peter}

The structure of 1 Peter has been analysed by Van Rensburg (1992: 26-41) and the results are presented below. After the letter heading (1:1-2), the letter opening follows (1:3-12), inter alia mentioning that God has given the readers new birth. This statement about their new birth then becomes the basis for four inferences which are given as four exhortations, viz 1:13-25, 2:1-10, 2:11-4:19, and 5:1-11.

This interpretation of the thought structure of 1 Peter can be represented in the following way, showing that 3:14-15 is interpreted as part of 1 Peter 3:13-22, which is a section of the third of four exhortations based as inferences ${ }^{4}$ upon 1 Peter 1:3-12:

3. 'Scripture in 1 Peter is essentially traditional, drawing on key psalms $(34 ; 40 ; 118)$, key chapters of Isaiah (8; 40; 53) and wisdom sayings, some of which are found elsewhere in the New Testament (Prov 3:34). Hanson thinks it lacks the profundity of Paul but it appears to be of the same general type' (Moyise 2001:116).

4. There is no relational particle (such as oùv or $\gamma \alpha \dot{\alpha} \rho)$ giving an explicit indication of the relation of 2:11ff with the preceding. When, however, the contents are taken into consideration, it can be argued that 2:1-4:19 functions on the same level as 1:13-25 and 2:1-10 (and 5:1-11), in other words 2:1-4:19 forms a third exhortation with the rebirth (1:3) as basis. 


\section{LETTER HEADING}

1:1-2: Author, addressees and greeting

\section{LETTER OPENING}

1:3-12: Praise be to God, the Father of our Lord Jesus Christ; $\mathrm{He}$ gave us new birth.

\section{FOUR INFERENCES WITH THE REBIRTH AS BASIS}

Inference 1: 1:13-25: Set your hope fully on the grace, and therefore be holy

Inference 2: 2:1-10: The obligation of a reborn person to grow individually, as well as together with fellow-believers

Inference 3: 2:11-4:19: Code of conduct for aliens

2:11-12: The basic exhortation

2:13-17: Relationship with political authorities

2:18-25: Relationship with employers

3:1-7: Relationship with the marriage partner

3: 8-12: Relationship with neighbours in general

3:13-4:19: Attitude towards and reaction to unjust sufferings

Inference 4: 5:1-11: Code of conduct within the church

\section{CONCLUSION}

5:12-14: Conclusion: Purpose, salutations, letter closing 


\subsection{The place of 3:13-17 within the section 3:13-4:19}

In $3: 13-4: 19$ the exhortation of $2: 11-12$ is applied to the attitude towards and reaction to unjust sufferings.

\section{The basic exhortation: Revere only Christ as Lord}

3:13-17: Even if you suffer for what is right, you are blessed. Revere only Christ as Lord (= Master)

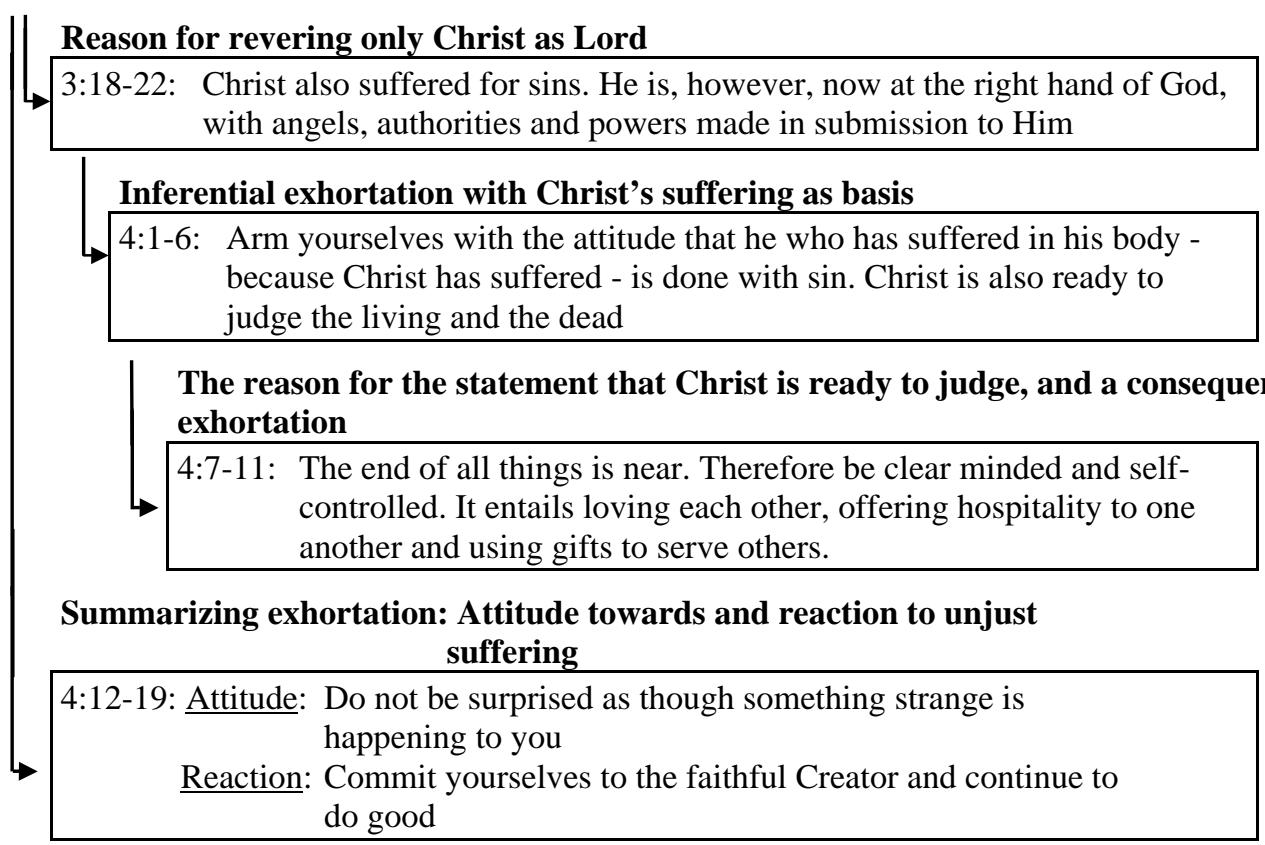

1 Peter 3:13-4:19 is interpreted as the fifth practical application of the basic exhortation in 2:11-12 on living as aliens. In the representation of this interpretation of the thought structure, 3:13-17 is interpreted as the basic statement, motivating the hearers to revere only Christ as Lord. The pericope 3:18-22 gives the reason for revering only Christ as Lord: because he has declared his victory even over the spirits in prison. The pericope 4:1-6 then follows as inferential exhortation with Christ's suffering as basis, motivating the hearers to arm themselves with the attitude that a person who has suffered in the body - because Christ has suffered - is done with sin. This pericope ends with the statement that Christ is ready to judge the living and the dead. The pericope 4:7-11 gives the reason for the statement that Christ is ready to judge, stating that the end of all things is near. The final pericope of this section is 4:12-19, a summarizing exhortation on the attitude towards and reaction to unjust suffering: the hearers should not be surprised as though something strange is happening to them, and they must commit themselves to the faithful Creator and continue to do good.

\subsection{The meaning of 1 Peter 3:14b}

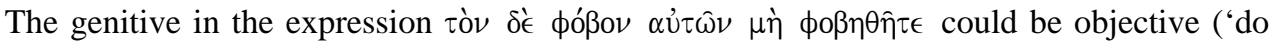
not fear them' - so NJB) or subjective ('do not fear what they fear ' - so NRSV, NIV). The 
latter is problematic, however, since the context is the prospect of unjust suffering being inflicted by those who wield authority. It is this that has caused the readers (quite naturally) to feel afraid. What those same leaders are themselves afraid of is beside the point. It is the threat that they currently represent that is causing the problems (see 4:12). Thus фóßov $\alpha \cup ่ \tau \omega \nu$ is not to be translated as 'their fear', which is misleading, but 'their threat' (so Selwyn 1947, Best 1971, Michaels 1988).

\subsection{The thought structure of 1 Peter 3:13-22}

The interpretation of the thought structure of 1 Peter 3:13-22 is as follows:

1 Peter 3:13-17: Basic exhortation for attitude towards and reaction to unjust suffering: Revere only Christ as Lord

Rhetorical question, functioning as basic statement
The opposite of the basic statement
3:14a: But even if you should suffer for what is right, you are blessed
Negative exhortation as implication of the basic statement
3:14b Do not fear their threat, nor be disturbed
Positive exhortation as implication of the basic statement
3:15a: But in your hearts revere only Christ as Lord
Practical implication 1 of the exhortation to revere only Christ as Lord
3:16: 1 : Keep a clear conscience
give the reason for the hope that you have

3.5 The argument of 1 Peter 3:13-17 summarised

- The basic positive exhortation of this pericope is that the hearers should revere only Christ as Lord (3:15a), i.e. they should accept Him as the One determining their lifestyle and attitude towards life.

- When believers fear the threat of those who would abuse them and become disturbed or troubled (3:14b), they allow these bad people lordship over their lives, de facto accepting them as the persons determining their lifestyle and attitude towards life.

- This insight makes clear how the two seemingly contradicting statements in 3:13-14a fit into the argument. The first statement of the pericope seems like good logic: Who is going to harm you if you are eager to do good? (3:13a). The author, however, 
immediately corrects himself, since he knows that many suffer for what is right. Therefore the statement: But even if you should suffer (optative) for what is right, you are blessed (3:14a). Being willing and able to "suffer for what is right" demonstrates that believers revere only Christ as Lord.

- Revering only Christ as Lord entails two practical matters: the believer will (1) Always be prepared to give an answer to everyone who asks you to give the reason for the hope that you have (3:15b), and (2) Keep a clear conscience (3:16b).

- The purpose of a clear conscience is given in 3:16c: so that those who speak maliciously against your good behavior in Christ may be ashamed of their slander.

- And in the final verse, 3:17, a reason is given for the exhortation to keep a clear conscience: For it is better, if it is God's will, to suffer for doing good than for doing evil.

\subsection{The communicational goal of 1 Peter 3:13-17}

You, being visiting and resident aliens, ${ }^{5}$, should deem yourselves blessed when you suffer for what is right. If you fear the threat these perpetrators embody and allow them to disturb you, you will want to retaliate. The moment you do this, you actually show that you have allowed the very same perpetrators to become "lords" of your life, determining your lifestyle and attitude. Therefore, revere only Christ as Lord by being ready to witness to your hope, and by keeping a clear conscience: The moment you retaliate, your conscience is no longer clear.

\section{Peter's utilisation of Isaiah as intertext in 3:13-17}

In this section, the most likely meaning of Isaiah 8:12-13 in its own context is discussed, and then 1 Peter's utilisation of the passage as intertext is explored.

\subsection{The text of Isaiah 8:12-13}

The following table sets out the Greek (Rahlfs) and Hebrew (BHS) of Isaiah 8:12-13, together with an English translation.

\begin{tabular}{|c|c|c|c|}
\hline $\begin{array}{l}\text { Isaiah 8:12-13 } \\
\text { LXX }\end{array}$ & $\begin{array}{l}\text { Isaiah 8:12-13 } \\
\text { Translation }\end{array}$ & $\begin{array}{l}\text { Isaiah 8:12-13 } \\
\text { BHS }\end{array}$ & $\begin{array}{l}\text { Isaiah 8:12-13 } \\
\text { Translation }\end{array}$ \\
\hline 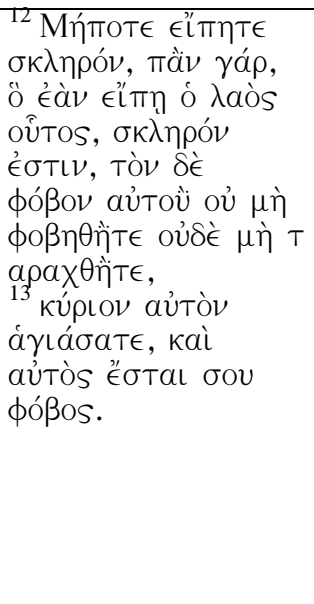 & $\begin{array}{l}12 \text { "Do not call } \\
\text { conspiracy } \\
\text { everything that } \\
\text { these people call } \\
\text { conspiracy; do } \\
\text { not fear its [his] } \\
\text { fear, and do not } \\
\text { dread it. } \\
{ }^{13} \text { The Lord is } \\
\text { the one you are } \\
\text { to revere, he is } \\
\text { the one you are } \\
\text { to fear. }\end{array}$ & 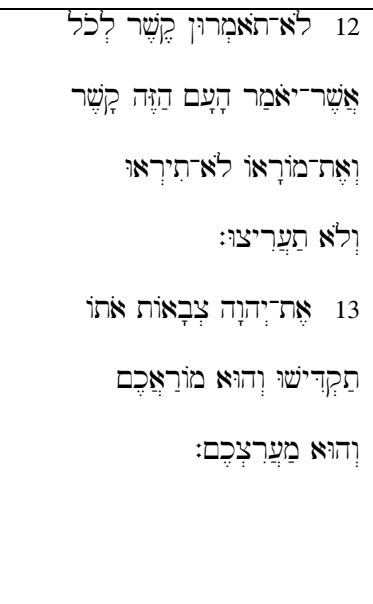 & $\begin{array}{l}12 \text { "Do not call } \\
\text { conspiracy } \\
\text { everything that } \\
\text { these people call } \\
\text { conspiracy; do not } \\
\text { fear what they } \\
\text { fear, and do not } \\
\text { dread it. }{ }^{13} \text { The } \\
\text { LORD Almighty } \\
\text { is the one you are } \\
\text { to regard as holy, } \\
\text { he is the one you } \\
\text { are to fear, he is } \\
\text { the one you are to } \\
\text { dread. }\end{array}$ \\
\hline
\end{tabular}

5. For the proposal of viewing the readers as 'resident and visiting aliens', see Van Rensburg 1998:573-584. 


\subsection{The meaning of Isaiah 8:12-13}

Isaiah 8:12-13 is part of the pericope 8:11-22, introduced by "The Lord spoke to me" (8:11), representing the fourth time that the Lord speaks to Isaiah. The primary context seems to be that represented by the term "conspiracy" (רשקp) (Seitz 1993:82). The conspiracy could refer to the "conspiracy" of Rezin and Pekah referred to in Isaiah 7:1-2 "so that the hearts of Ahaz and his people were shaken, as the trees of the forest are shaken by the wind" (Widyapranawa 1990:48). Those who are faithful are called upon not to be dragged along in fear and trembling, but to fear only God. The implication is that they should expect from him deliverance.

Another possibility is that the conspiracy actually refers to the prophet, since he has pronounced judgement over the royal house (so Seitz 1993:82). He is therefore likely to be considered a conspirator by many. The charge of the pericope then is that the prophet should not regard the charge of conspiracy as accurate; he is not to fear the Syro-Ephraimite threat, as do others; he is to fear God alone.

What is clear is that the 'fear' that the prophet is to avoid is the fear sweeping over the people. It is not fear of the people but the fear that has captivated the people. It has been

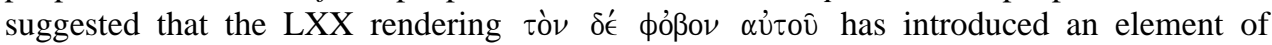

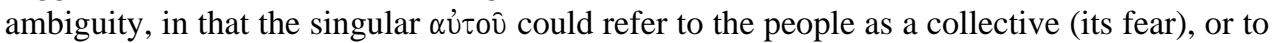
an individual (his fear), presumably, the king of Assyria. Michaels (1988: 186) thinks this opens up the possibility of taking the text in an objective sense ("Do not fear the fear that he produces").

\subsection{The text of Isaiah 8:12-13 in 1 Peter 3:14-15}

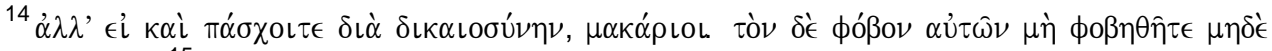

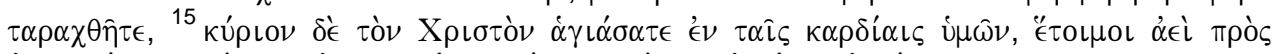

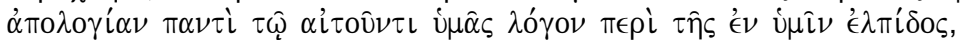

Though the author does not introduce the words of Isaiah 8:12-13 with an introductory formula, it is clear that it is an explicit quotation, for: (1) The abrupt and somewhat unusual

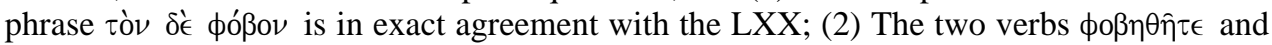
$\tau \alpha \rho \alpha \chi \theta \eta \tau \tau$ are identical to the LXX; ${ }^{6}$ (3)There follows a contrasting command to reverence $(\dot{\alpha} \gamma\llcorner\dot{\alpha} \sigma \alpha \tau \epsilon)$ the Lord. The author is clearly wishing to direct his readers to the LXX of Isaiah 8:12-13.

However, having ascertained the author's intention to quote, it is now necessary to explore the differences between the two texts:

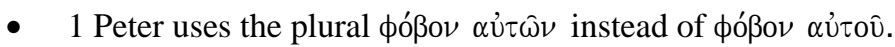

- 1 Peter uses the less emphatic $\mu$ ì instead of oủ $\mu \grave{n}$

- 1 Peter uses $\mu \eta \delta \dot{~ i n s t e a d ~ o f ~ o u ́ \delta ́ ் ~} \mu \grave{\text {. }}$

- 1 Peter commands revering Christ as Lord instead of the Lord God.

\subsection{The meaning of Isaiah 8:12-13 as quoted in 1 Peter 3:14-15}

The second and third of the differences noted above are probably no more than stylistic variation but the first and last are of some significance. As we have already established, the

6. Some manuscripts (p72, B, L) omit $\mu \eta \delta^{\prime} \epsilon \alpha \rho \alpha \chi \theta \hat{\eta} \tau \epsilon$ and one could argue that a later scribe has added them in order to conform the text more closely to the LXX. However, the words are well attested and probably slipped out because of the common ending with $\phi \circ \beta \eta \theta \hat{\eta} \tau \epsilon$. 
meaning of 1 Peter $3: 14 \mathrm{~b}$ is that the readers are not to fear those who threaten to abuse them. The meaning of Isaiah 8:12-13, in its own context, is that the prophet is not to fear

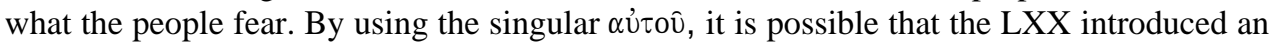
element of ambiguity (so Michaels), since it could refer to an individual, namely, the king of Assyria. The author of 1 Peter, however, replaces the singular au่ ô with the plural $\alpha \bigcup \tau \omega \hat{\nu}$, confirming our previous conclusion that his meaning is "do not fear them". As Best (1971:132) says:

In Isaiah the prophet is told not to fear the king of Assyria as the Israelites do; here the meaning has been changed; when the words are isolated from their own context they can be translated as in 1 Peter; the original meaning 'do not fear with their fear' would be impossible in the context of 1 Peter.

The second change is a fairly common one in Christian exegesis (eg. Phil 2:10), that is to interpret a reference to God as kúpıos as a reference to Christ as kúpıos. It does not appear that the author is trying to defend a specific Christological argument here for he simply assumes it (see 1:25; 2:3). Michaels (1988:187) thinks he is preparing for the

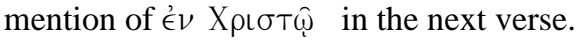

Why then does the author of 1 Peter incorporate a quotation from Isaiah 8:12-13 when on two important points, it does not agree with what he wants to say? As Selwyn (1947:192) says, the author's Greek would have been a lot more straightforward had he just

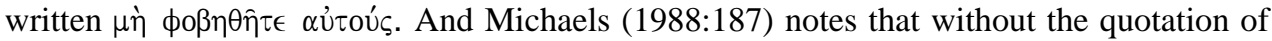
Isaiah 8:12-13, $\phi \circ \beta \eta \theta \hat{\eta} \tau \epsilon \mu \eta \delta \dot{\epsilon} \tau \alpha \rho \alpha \chi \theta \hat{\eta} \tau \epsilon$ would most naturally have been seen as a reference to the dominical words now found in Matthew 10:26-33 and John 14:1. Why then did the author of 1 Peter introduce a quotation from Isaiah 8 which at two important points, differed from what he wanted to say?

\section{An intertextual explanation}

\subsection{There is a further text lurking in the background}

It would not be out of keeping with the New Testament use of the Old to sometimes employ phrases for their evocative power rather than contextual meaning. However, given our authors rich use of Isaiah texts, it is worth investigating if Isaiah 8:12-13 might have suggested to the author of 1 Peter another text from Isaiah which more specifically draws a contrast between fear of God and fear of men. Isaiah 51:12-13 is one such text:

I, even I, am he who comforts you. Who are you that you fear mortal men, the sons of men, who are but grass, that you forget the LORD your Maker, who stretched out the heavens and laid the foundations of the earth, that you live in constant terror ('€́óßou $\alpha \in \dot{\alpha}$ ) every day because of the wrath of the oppressor, who is bent on destruction? For where is the wrath of the oppressor?

The echo is certainly faint in terms of identical wording, but it is perhaps significant that the reason given for why the people should not fear human opponents is that they "are but grass". The author has already quoted Isaiah 40:6-8 to make the point that "all men are like grass" (1:24-25). Is this then the unquoted intertext that lurks in the background and explains how the author can move from "men as grass" and "do not fear what they fear" to the conclusion "do not fear their threat"? 


\subsection{The ancient text continues to speak through the new writing}

Though it is perfectly possible to make sense of 1 Peter 3:13-17 without knowledge of Isaiah 8:12-13, the quotation introduces a second source of meaning. The main source is the argument pursued in 1 Peter and outlined above in section 3. But the explicit reference to Isaiah 8:12-13 now suggest to the reader that "text B should be understood in light of a broad interplay with text A, encompassing aspects of A beyond those explicitly echoed" (Hays, 1989:20). In other words, having directed the reader to the themes and connotations of Isaiah 8:12-13, the author cannot now control how these themes will affect a reading of the text. For example, the use of $\dot{\alpha} \gamma\llcorner\dot{\alpha} \sigma \alpha \tau \epsilon$ evokes a theme that runs through the whole of Scripture, namely, God's absolute holiness and the corresponding injunction to "have no other gods before me" (Exod 2:3). The readers of 1 Peter are being told to face suffering the way that Christ faced suffering. But the powerful associations of $\dot{\alpha} \gamma \dot{\alpha} \alpha \alpha \tau \tau \in$ raise the stakes and suggests that their loyalty to Christ should be like the absolute loyalty demanded by God throughout Scripture.

Similarly, although the context suggests that the meaning of 1 Peter $3: 14 \mathrm{~b}$ is "do not fear them" rather than "do not fear what they fear", the meaning of Isaiah 8:12-13 might well add a subsidiary voice, namely, "do not fall into fear the way that non-believers do". In regard to the persecutors, it is not what they fear but the 'fear of them' that is in mind. But in regard to ordinary non-believers, they are to show themselves different by not giving in to fear and thereby bearing witness to the hope that is within them. That this is a real

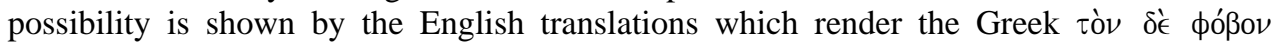
$\alpha \dot{\nu} \tau \hat{\omega} \nu \mu \grave{\eta} \phi о \beta \eta \theta \hat{\eta} \tau \epsilon$ "do not fear what they fear". The reader is presumably meant to deduce that the pronoun "they" does not refer to those who will "harm you" but to the general public:

Now who will harm you if you are eager to do what is good? But even if you do suffer for doing what is right, you are blessed. Do not fear what they fear, and do not be intimidated, but in your hearts sanctify Christ as Lord (NRSV).

\subsection{The clash of contexts generates a creative tension}

To draw attention to a text only to change its meaning can have a number of effects: (1) If the text is powerful and well-known, it might be dismissed as misappropriation; ${ }^{7}$ (2) If the text is not well known it may simply be accepted as the true interpretation; (3) Well known or not, it might be taken as shorthand for "this is the meaning of the text in the light of what has now been revealed"; (4) It might produce a tension that is not easily resolved. In his analysis of Renaissance poetry, Thomas Greene (1982:46) speaks of dialectical imitation, where texts sometimes engage one another at such a level that the text becomes "the locus of a struggle between two rhetorical or semiotic systems that are vulnerable to one another and whose conflict cannot easily be resolved".

Readers of 1 Peter are told to revere Christ as Lord, while at the same time being directed to a verse that insists that God alone is to be revered. It is not Peter's purpose to suggest that Christians should stop revering God and start revering Christ. But the tension produced by these two statements will occupy the Church for many centuries to come. Foregoing the Marcionite option of simply rejecting the Jewish scriptures, the early Church had to wrestle with twin sources of authority which were not easily reconciled. There is no hint that the author of 1 Peter thought he was saying something daring or controversial. Quite the opposite; he appears to be echoing common Christian belief. But the dynamic let

7. See Moyise (2002) for a discussion of what might constitute appropriation or misappropriation. 
loose by quoting a text that demands absolute loyalty to God and relating it to Christ was not so easily contained. Though apparently unproblematic to the author of 1 Peter and his readers, it was not unproblematic for future generations.

\section{Conclusion}

The utilisation of Isaiah in 1 Peter 3:13-17 is both straightforward and complex. From a structural analysis of 1 Peter, it seems relatively clear what the author is trying to say: Do not allow fear to govern your behaviour but revere Christ as Lord. And the quoted text says much the same thing: Do not fear what they fear but revere the Lord your God. However, there are two points of dissonance as these texts are brought together. The first is the change from fearing what they fear to fearing them. The second is that the author urges his readers to revere Christ as Lord. Traditional exegesis might comment that the author has simply changed the meaning of Isaiah to suit his purposes (e.g. Best). But an intertextual approach seeks to give an account of the new figurations that are generated by such dissonance. Some of these might have been intended by the author. But some are the product of bringing Isaiah 8:12-13 and the argument of 1 Peter 3:13-17 into close correspondence. It is the task of intertextuality to explore the ongoing effects of producing such a correspondence and it is hoped that this article represents a contribution to that process. 


\section{REFERENCES}

Aichele, G \& Phillips, GA 1995. Introduction: Exegesis, Eisegesis, Intergesis. Semeia 6970:7-18.

Aland, BA, Kurt, Karavidopoulos, J, Martini, CM, Metzger, BM (eds.). 1993 (Fourth Revised edition). The Greek New Testament. Stuttgart: Deutsche Bibelgesellschaft.

Best, E 1971. 1 Peter. New Century Bible. London: Marshall, Morgan \& Scott.

Bratcher, RG (ed.). 1967. Old Testament quotations in the New Testament. London: United Bible Societies.

Hays, RB 1989. Echoes of Scripture in the Letters of Paul. New Haven: Yale University Press.

Hollander, J 1981. The Figure of Echo: A Mode of Allusion in Milton and After. Berkeley: University of California Press.

Kristeva, J 1986 [1969]. Word, Dialogue and Novel (in Moi, T (ed.), The Kristeva Reader, New York: Columbia University Press).

Michaels, JR 1988. 1 Peter. Word Biblical Commentary 49. Texas: Word Books.

Miscall, PD 1992. Isaiah: New Heavens, New Earth, New Book (In: Fewell, DS (ed.), Reading Between Texts. Intertextuality and the Hebrew Bible, Louisville, KY: Westminster/John Knox Press).

Moyise, S 2000. Intertextuality and the study of the Old Testament in the New. (In: Moyise, S (ed.), The Old Testament in the New. Essays in honour of JL North. Sheffield: Sheffield Academic Press. (JSNTS up 189). pp.14-41.

Moyise, S 2001. The Old Testament in the New. An introduction. London: Continuum.

Moyise, S 2002. Does the author of Revelation misappropriate the Scriptures? Andrews University Seminary Studies 40: 1-22.

Porter, SE 1997. The Use of the Old Testament in the New Testament: A Brief Comment on Method and Terminology. (In: Evans, C \& Sanders, J (eds.), Early Christian Interpretation of the Scriptures of Israel. Investigations and Proposals (JSNTS up 148, Studies in Scripture in Early Judaism and Christianity, 5). Sheffield: Sheffield Academic Press). pp.79-96.

Rahlfes, A (ed.) 1935. Septuaginta, id est Vetus Testamentum graece iuxta LXX interpres (Volumes I and II). Stuttgart: Deutsche Bibelstiftung.

Seitz, CR 1993. Isaiah 1-39. (Interpretation: a Bible commentary for teaching and preaching). Louisville: John Knox Press.

Selwyn, EG 1947. The First Epistle of St. Peter. London: Macmillan \& Co.

Van Rensburg, FJ 1992. The outline of 1 Peter: A reconsideration. Ekklesiastikos Pharos 74/1: 26-41.

Van Rensburg, FJ 1998. Christians as 'resident and visiting aliens'. Implications of the exhortations to the 'paroikoi' and 'parepidemoi' in 1 Peter for the church in South Africa. Neotestamentica 32(3): 573-584.

Vorster, WS 1989. Intertextuality and Redaktionsgeschichte. (In Draisma, S (ed.), Intertextuality in Biblical Writings (Festschrift B. van Iersel). Kampen: Kok). pp.1526.

Widyapranawa, SH 1990. The Lord Is Savior: Faith In National Crisis. (International Theological Commentary, Isaiah 1-39. 